\section{Six decades of the Israeli-Arab conflict: an assessment of the economic aspects}

Aamer S. Abu-Qarn

$\mathrm{S}$ ix decades have elapsed since the establishment of the state of Israel and, with it, the inauguration of the Israeli-Arab conflict in 1948. Several fierce wars have been fought (in 1948, 1956, 1967, and 1973) with Israel facing three major Arab neighbors, Egypt, Jordan, and Syria. The warring parties allocated a sizeable fraction, unparalleled in international standards, of their scarce resources to maintain their military capabilities and prepare for the next confrontation. With Egypt and Jordan signing peace treaties (in 1979 and 1994, respectively), Syria remained the lone member of the front line that is, at least officially, in a state of war with Israel. In spite of this, Syria as well as the other countries drastically cut their military expenditure to channel resources from the military to the civilian sectors.

Although the Israeli-Arab conflict is one of the longest-running and most influential conflicts in the world, it has received only modest attention by economists, mainly due to lack of reliable data. Interest in nonmilitary aspects of the region's economies is low as well even though it plays a significant role in the world economy. This article provides a critical survey of the literature that addresses the economic aspects of the conflict.

The next section sketches the chronology of the conflict. The sections thereafter cover the following topics: first, data sources and the lack of trustworthy, detailed time series that would enable researchers to address a wider and richer array of issues; second, the determinants of military expenditure and the existence of arms race between Israel and its Arab neighbors; third, the relationship between military outlays and economic growth and whether military spending has an adverse impact on the economies; fourth, the effects of foreign military and civilian aid on the Israeli-Arab conflict; and, finally, analysis of the benefits (and costs) of a just and sustained peace in the region. Although the issues are interrelated and often hard to detach, dividing the survey into several topics facilitates rigorous comparative analysis with other regions and economies. The concluding sections offers some guidelines for future research.

\section{A conflict chronology}

Following World War I and the collapse of the Ottoman Empire, Great Britain was granted a mandate over Palestine by the League of Nations with the stated objective of putting into effect the 1917 promise of a national home for Jews in Palestine. The Arab people of Palestine opposed the terms of the mandate, especially the lack of reference to their own political and national rights. In 1947 the United Nations proposed a Partition Plan that called for the establishment of two independent states in Palestine, one for Arabs and one for Jews. Arabs rejected this and shortly after the withdrawal of British forces and the independence declaration of Israel they declared a war on Israel. The 1948 war resulted in hundreds

of thousands of Palestinians fleeing or being expelled into neighboring Arab countries.

The next war took place after the nationalization of the Suez Canal by Egyptian President Abdel Nasser and the blockade of the Tiran Straits to Israeli ships in 1956. Israel, supported by Britain and France, invaded and occupied the Sinai peninsula and Gaza Strip. Soviet and American pressure forced the three parties to withdraw from the occupied lands by early 1957. Ten years later, in June 1967, Israel launched a quick and massive attack that lasted for only six days and took the Sinai peninsula and Gaza Strip from Egypt, the West Bank, including Eastern Jerusalem, from Jordan, and the Golan Heights from Syria. The decisive defeat of Arabs changed the Israeli-Arab conflict and the region's political structures radically.

On 6 October 1973, the holy Jewish Yom Kippur, Egypt and Syria coordinated a joint attack, advanced beyond the cease-fire lines into Sinai and the Golan, and inflicted heavy casualties on the Israeli army. Israel counter-attacked and succeeded to drive the Egyptian and Syrian armies back and advanced well into their respective territories. The war ended with a ceasefire that paved the way for peace negotiations between Egypt and Israel which culminated in a peace treaty in 1979. The agreement ended the state of war between the two countries, Israel pulled out its armed forces and civilians from Sinai, and normal diplomatic relations were established. However, this dramatic Egyptian move was opposed by a unified Arab front that objected to a unilateral peace treaty which neglected the Palestinian issue.

On June 1982, Israel attacked Palestinian targets in southern Lebanon with the stated objective of pushing Palestine Liberation Organization (PLO) forces, that were attacking northern Israel, farther to the north. Israel extended its operations deep into Lebanon beyond the initial plan and many Lebanese cities, including Beirut, and Syrian military targets in Lebanon were bombed and suffered heavy destruction and casualties. After a long siege of Beirut, PLO forces were forced out of Lebanon and Israel withdrew from most of the Lebanese territories. However, Israel maintained a security zone of approximately 10 miles north of the border that was eventually evacuated in 2000

Two decades of Israeli occupation with no sign of progress toward a permanent 
solution to the Palestinian nationalistic claims have led to the eruption of an intifada (Arabic for popular uprising). The uprising began in Gaza and spread all over the occupied territories. It involved hundreds of thousands of people and included not only stone throwing, burning tires, Molotov cocktails, and the erection of barricades but also massive demonstrations, general strikes, refusal to pay taxes, and boycott of Israeli products. The Palestinian uprising continued, although at a lower intensity, until the signing of the Oslo Accords in 1993. In the midst of this period Israel suffered a missile attack by Iraq when the United States, backed by an international coalition, drove Iraq out of Kuwait in 1991. In the aftermath of the Gulf War, direct negotiations between Israel and Arab countries were initiated in Madrid under the supervision of the United States and the then-Soviet Union.

Several rounds of negotiations and the subsequent recognition of Israel by the PLO brought Israel and the PLO together for intensive rounds of confidential talks that led to the signing of the Oslo Accords on 20 August 1993. The Accords called for the withdrawal of Israel from parts of Gaza Strip and the West Bank and for the establishment of a Palestinian Authority and negotiating for a permanent agreement that would begin no later than August 1996. The progress in the Palestinian channel led to a peace treaty between Israel and Jordan in 1994 under which all the territorial and water disputes were resolved, and relations were normalized.

The outbreak of the Al-Aqsa intifada in 2000 marked the escalation of hostile actions by Palestinians and Israelis when the negotiations on a permanent agreement ended in a deadlock. In August 2005, Israel unilaterally withdrew from the Gaza Strip and some settlements in the West Bank. Following the kidnapping of two Israeli soldiers in southern Lebanon by Hezbollah in July 2006, Israel raided Lebanon in what later was called the Second Lebanon War.

In June 2007, Hamas violently routed Fatah forces in Gaza and established another Palestinian government beside the one that resides in Ramallah; however, it received neither Arab nor international recognition.

\section{Data issues}

Data on the Israeli-Arab conflict is scarce and what little is available is often treated with skepticism. Governments in the region do not reveal accurate measures of the strength of their military forces and, worse, they might intentionally provide erroneous reports. Researchers have no choice but to rely on official reports or data sets compiled by international organizations. Thus, data issues are always raised as possible explanations for some of the findings and anomalies in the conflict literature.

By far the most comprehensive and reliable source of data on military expenditure and arms is the Stockholm International Peace Research Institute (SIPRI). Currently, consistent data is provided only for the period 1988-2006. Most researchers resort to splicing data from earlier editions even though SIPRI explicitly warns that due to continuous revisions of military figures, data are not necessarily comparable. This practice among researchers challenges the reliability of their conclusions.

While SIPRI does its best to assure consistency, it relies greatly on official data that in the case of Middle Eastern countries is highly questionable. SIPRI strives to include all military-related activities and purchases even if they are classified under civilian budgets. But the ability to do so is confined by the usually highly aggregated data the governments release in order to conceal certain military expenses.

Another major source of data is World Military Expenditures and Arms Transfers (WMEAT), compiled by the U.S. Department of State's Bureau of Verification, Compliance, and Implementation. Although no longer updated, the reports have raised serious concerns with regard to the reliability of the data of many developing countries, including some in the Middle East. Specifically, there are reasons to believe that the military expenditure of these countries consist mainly or entirely of recurrent or operating expenses and omit most of the capital expenditure and arms purchases Additionally, governments may use double bookkeeping, extra budgetary accounts, highly aggregated budget categories, military aid, and exchange rate manipulations to obscure large portions of military expenditure. Thus, to provide better estimates, the Bureau suggests adding the value of arms imports to the reported expenditure. It acknowledges, however, that this may then overstate actual expenditure.

Other data issues include off-balance sheet defense costs that are excluded from official defense spending accounts, such as conscripts' and reservists' imputed wages (the difference between the official and the opportunity costs), actuarial cost of medical care and disability resulting from military activities, costs of holding strategic stockpiles, and costs of air-raid shelters. These items are crucial in the case of Israel that has a long mandatory military service term (three years for males and two years for females) as well as a reserve service requirement of up to 36 days per year until the age of 51.

To better examine defense-related issues, researchers need disaggregated data on many civilian-type activities that might be classified as military-type expenditure as well as on civilian-type expenditure that are included in the military budgets in order to compile reliable and comprehensive series on military outlays. Additionally, time series on the number of army personnel, arms arsenals, and procurements would significantly enhance our understanding of the evolution of the Israeli-Arab conflict and its dynamics.

\section{The Israeli-Arab arms race}

An arms race refers to a state of enduring rivalry between two or more parties under which the rivals build up their military capabilities in an action-reaction framework (Richardson, 1960). Many econometric methodologies have been applied to examine the existence of arms races among potential rivals. An excellent survey of these methods is provided by Smith, et al. (2000). Here, the literature that deals with the existence and direction of the Israeli-Arab arms race is surveyed. Analysis is usually 
conducted in the context of the determinants of military expenditure or using traditional causality tests.

To analyze determinants of Israeli military expenditure over the period 1960-1979, McGuire $(1982$; 1987) estimates a multiequation model using the Full Information Maximum Likelihood (FIML) method. The analysis reveals that the responsiveness of Israel to its Arab adversaries is very modest whereas Arab's responsiveness to changes in Israeli military spending is relatively high. The author takes into account the effect of American aid to Israel and finds that military aid is used to offset the effect of rising Arab spending. Both studies suffer from the short time span for which the analysis was conducted. Furthermore, the detection of first order autocorrelation coefficients that are close to unity is problematic and renders the results dubious.

Mintz and W ard (1989) show that Israel's spending is driven, among other factors, by Arab military expenditure. However, they estimate a system of equations in which the latter is exogenous. Despite the impressive fit of their regressions, the results indicate severe autocorrelation. ${ }^{2}$

While these studies focused on determinants of military spending, several studies adopt causality tests to assess the existence of an arms race between Israel and its rivals. In an early study, Linden (1991) applies Granger causality for Israel and Arab countries. He finds that there is a causal almost one-to-one equilibrium relationship that runs from Israel's to the Arab bloc's level of military expenditure. However, he finds that disequilibrium behavior dominates Israeli spending as it reacts only to current changes in the Arab bloc's level of military expenditure. He thus concludes that the arms race system between the two adversaries is rather unstable.

Chen, et al. (1996) use cointegration methods to investigate the existence of collective action among the Arab countries neighboring Israel. They show that up to the late 1970s, Egypt was the only Arab country involved in a fierce arms race with Israel and that the long-run equilibrium relationship disappeared after the signing of the 1979 peace treaty. The authors find that a long-run equilibrium with a weak Arab response was established between the defense spending of Israel and the minor front line countries (Jordan, Lebanon, and Syria), indicating that these countries did not take the opportunity for complete free-riding. Furthermore, they conclude that collective action among the four Arab countries constituting the front line with Israel may be valid.

A vector error correction, or VEC, model is used by Beenstock (1998) to uncover causality between Israel's military expenditure and a host of endogenous variables, including military spending by the Arab confrontation states and U.S. military aid over the period 1960-1994. He detects causality from Arab military spending to Israel's when using the Engle-Granger VEC but fails to do so when using the Johansen-based VEC. The author does not report tests of causality running in the other direction. When examining the effect of U.S. aid, the author postulates that American aid does not play a major role in Israel's long-run decisions on military spending.
In an attempt to examine the existence of arms races among several likely adversaries, including Israel and its Arab neighbors, Seiglie and Liu (2002) apply VEC Granger causality for bivariate, trivariate, and quadvariate VARs over the period 1948-1991 for various combinations of Arab countries (Egypt, Iraq, Jordan, and Syria) and Iran with Israel. They find that for most cases causality runs from Israel's to individual and combinations of two or three Arab countries' military spending. Furthermore, the evidence of causality running from Arab to Israel's military expenditure is weak or nonexistent.

Deviating from traditional analysis, Sprecher and DeRouen (2002) use data on military actions, rather than on military expenditure, to conduct VAR-based causality tests over the 1948-1998 period. They find that Israeli military actions are driven by both Arab military actions and by domestic political protests, while Arab military actions are driven by Israeli military actions and seem to decrease in response to Israeli actions. Thus, they uncover a two-way causality between the military actions of the rivals.

All of the studies that employ traditional Granger causality use the Wald test for exact linear restrictions that has been shown to have nonstandard asymptotic properties if the variables in the VAR are integrated or cointegrated. ${ }^{3}$ Moreover, the need for pretests for unit roots and cointegration, and the inapplicability when the variables have different orders of integration, further add to the distortions associated with Granger causality from within VAR or VEC settings. A recent causality procedure by Toda and Yamamoto (1995) requires the estimation of an augmented VAR that guarantees the asymptotic distribution of the Wald statistic. Also, the procedure does not require pretesting for integration or cointegration properties of the VAR system. The procedure has been applied by Abu-Qarn and Abu-Bader (2008). They find that causality runs, in general, from Israel's military spending to Arab's and that Israel and Syria are engaged in a two-way arms race.

Overall, the bulk of studies surveyed in this section point to a one-way arms race from Israeli to Arab spending. A possible explanation, suggested by McGuire (1982; 1987), is the generous American military and civilian aid to Israel, and the unconditional, instantaneous assistance that Israel received in emergencies such as in 1973. This aid is used to offset the expansion in Arab's military spending.

The defense-growth nexus

Economists have long debated how military spending affects economic growth and whether causality runs from defense to growth or vice versa. On the one hand, military spending, as is the case with other government expenditure, may impede economic growth by crowding-out private investment. Higher military expenditure may also result in distorted resource allocations, and the diversion of resources from productive activities to the accumulation of armaments and the maintenance of military forces. However, only a small portion, if any at all, of the decrease in military 
expenditure of the least developed countries (LDCs) may be channeled to productive investment. Therefore, reducing military spending per se may not necessarily enhance economic growth. Moreover, military spending could have a positive effect on growth by contributing to the civilian economy indirectly via enhanced accumulation of human capital and through spillovers of military R\&D. In principle, military spending can also affect economic growth positively through the expansion of aggregate demand (the Keynesian multiplier effect). The resulting increased demand leads to increased utilization of otherwise idle capital, higher employment and profits, and therefore higher investment.

Causality may also run the other way around, from economic growth to defense. Joerding (1986), for instance, claimed that a growing country may want to strengthen itself against foreign or domestic threats by increasing its military spending. Also, a growing economy may choose to pour some of the resources generated by growth to enhance its military capabilities.

For the major rivals in the Israeli-Arab conflict, only a few studies have addressed the relationship between defense and economic growth. Often the analyses are conducted in the context of assessing the dividends of cutting military spending. Most studies carry the implicit assumption of causality running from military expenditure to economic growth even as the opposite direction of causality is theoretically plausible as well. The findings are inconclusive and vary depending on the countries, samples, and econometric methods. ${ }^{4}$

Lebovic and Ishaq (1987) use a three-equation model employing panel data techniques for 20 Middle Eastern economies over the period 1973-1982. They find that military spending impedes economic growth for various groups of countries and for different alternative measures of military burden (military spending as a percentage of GDP). These conclusions are shared by Linden (1992) who used an augmented two-sector growth model to study the effect of military burden on growth for a panel of 13 Middle East countries from 1973 to 1985 applying generalized least squares regression. But opposite findings are reported by Cohen and Ward (1996) who estimate a single equation model that relates growth to investments, military and nonmilitary government spending, and population growth. They find that the benefits from military spending are large and affect growth positively, irrespective of the time period. Thus, they confirm the existence of a Keynesian multiplier effect that is roughly equivalent for both military and nonmilitary government expenditure.

Mixed results were reported by DeRouen (1995) who examined military expenditure of Israel, Egypt, Jordan, and Syria for the period 1953-88. He suggests that Egypt and Syria would realize dividends from slashing their military spending only if they increased allocations to nonmilitary government spending. As to Israel, he asserts that defense cuts alone may deter growth in the short-run. Furthermore, he finds that military spending has had a negative effect on growth after 1967 coupled with positive military spillover effects on civilian output. Surprisingly, DeRouen (1995) finds that the defense sector in Jordan is very productive and therefore military expenditure cuts would not lead to higher growth there. ${ }^{5}$

These studies did not explicitly take into account that causality could run from growth to defense. Abu-Bader and Abu-Qarn (2003) accommodate that possibility by applying causality tests and variance decomposition techniques to uncover the direction of causality between defense and growth for Egypt, Israel, and Syria. They find that in a trivariate setting (government civilian expenditure, military spending, and growth) there is evidence for bidirectional causality (from growth to military expenditure and vice versa) and that a higher military burden negatively affects economic growth for all countries, whereas civilian government expenditure positively affects growth in Egypt and Israel.

Another recent study, by Yildirim, et al. (2005) that covers 13 Middle Eastern countries and applies dynamic panel data methods, corrects for biases caused by using traditional panel data methods. It finds that military expenditure enhances economic growth in the Middle East.

Several studies have focused on the defense-growth nexus in Israel itself. Cohen, et al. (1996) tackled the relationship by emphasizing indirect linkages via investment and labor. They estimate a dynamic three-equation (investment, labor, and growth) model for the period 1960-1992 and conclude that benefits for Israel from cutting military spending are small (but positive), normally delayed for several years, and operating indirectly through positive effects on investment levels. The indirect positive impact through investments was captured as well by Looney and Winterford (1995) for the period 1955-1987. They found no support for negative effects of high military burden on the Israeli economy, and attribute this mainly to American assistance to Israel. Most studies use models that assume a linear relation between military expenditure and growth (and other variables). But evidence of nonlinearity in the defense-growth relationship is reported by Bichler and Nitzan (1996). They claim that throughout the $1950 \mathrm{~s}$ and most of the $1960 \mathrm{~s}$ military expenditure had a positive effect on growth through accumulation of human capital and smoother assimilation of new immigrants. However, since the late 1960, large defense budgets led to higher national debt and slower growth. DeRouen (2000) further analyzed the effect of military and nonmilitary government spending on Israel's economic growth in a three-sector production function model for the years 1953-1992. His nonlinear least squares regression estimates suggest that when controlling for technological growth, short-term increases in military expenditure hinder economic growth whereas nonmilitary spending has the opposite effect. Based on his findings, he recommends using saved resources from peace for infrastructure and private investments.

The mixed evidence may be due to the different methods, samples, and time periods used in these studies. Israel's advanced military industries seem to have some spillover effects to the civilian sectors that reduce or offset the likely negative impact of military expenditure on the economy. But no such evidence is found for Israel's rivals, with the exception of DeRouen (1995) who asserts that the Jordanian military sector is very productive. More detailed studies that decompose military expenditure 
into its constituent parts (wages, equipment, etc.) and link them to different economic activities might yield some value added that would enhance our understanding of the potential gains in an era of Middle Eastern peace.

\section{Foreign aid}

Due to the strategic significance of the region, the Israeli-Arab conflict involved not only Israel and its neighbors but also other Arab countries as well as the superpowers that acted to maintain and strengthen their interests in the region by supporting one or more of the rivals. The United States and the former Soviet Union actively intervened in the region in the form of military and economic aid, in addition to providing top-of-the-line arms and training services. The region served as a battle ground in which American and Soviet arms and expertise competed against each other. Several studies have analyzed the role that foreign aid, in general, and of the superpowers, in particular, have played in the conflict. Most studies have addressed the effects of American military and economic aid to Israel (totalling around \$3 billion per annum). The support of the oil-rich Gulf states to the frontline countries did not receive due emphasis mainly because of lack of accurate estimates of its magnitude.

When assessing the determinants of Israeli military spending in a multi-equation setting that includes Arab demand for military expenditure and the determinants of U.S. assistance, McGuire (1982) finds that civilian aid is used by Israel as another source of fungible revenue, whereas military aid is strictly allocated for military use to offset the rise in Arab military expenditure. He concludes that American aid is unlikely to fuel the arms race in the region since the United States' propensity to spend additional resources in reaction to Arab military expenditure stands only at $\$ 0.1$ for every $\$ 1$ of Arab outlay. Similar conclusions are presented in McGuire (1987). In this extension of the earlier paper, McGuire asserts that American aid creates a modest indirect stimulus to investment through the complementarity between investment and defense but that it provides significant resources to the private sector through tax relief. Thus, American aid contributes to capital formation and growth via diversion of resources.

David Kinsella (1994a; 1994b) addresses the differences between the impact of American and Soviet arms transfers on a weighted index of conflict behavior in the region where events are classified into several categories ranging from verbal hostility to wars. Utilizing cross-correlation analysis, Granger-causality tests, and variance decompositions, he argues that Soviet, more than American, arms transfers have intensified the conflict. Moreover, Soviet arms transfers to Arab states have encouraged compensatory arming of Israel by the United States. Kinsella and Tillema (1995) conduct a similar analysis based on Poisson regression analysis of time series for the period 1948-1991, with data obtained from the Overt Military Interventions database that documents combat-ready military operations undertaken by the military forces of one country within foreign territory. The database includes operations by conventional ground combat units, commando raids, aerial attacks, artillery and rocket attacks, and naval attacks. The authors confirm the findings of Kinsella (1994a; 1994 b) by using different indicators, operational definitions, and data sources. They attribute their findings to the inability and unwillingness of the Soviet Union to use arms transfers to moderate Arab behavior rather than to its active promotion of the conflict.

In a follow-up article to Kinsella and Tillema (1995), Mayer and Rotte (1999) use multiplicative Poisson model that allows for variation in the impact that the superpowers may have had on interventions in the region, depending on the intensity of arms transfers. The authors validate Kinsella and Tillema's conclusions that American arms transfers decreased the likelihood of military intervention in the region whereas Soviet arms transfers did not. However, they find that the stabilizing effect of arms transfers clearly decreased with total arms transfers delivered to the region.

A different angle on the role that foreign aid may play in the conflict is portrayed by Beenstock (1998). Using an error correction model and causality tests to characterize Israeli military expenditure, he argues that American military assistance did not constitute a significant factor in the long-run and that Israeli military spending was not conditional on American assistance.

Summing up, the evidence in the literature hints at a positive role of American aid both on Israel's economy as well as on the likelihood of military intervention in the region, whereas Soviet arms transfers to Arab countries did not play such a role. The massive Arab aid to the frontline countries needs to be addressed in future research.

\section{Peace dividends}

Bringing the conflict to a halt, and ceasing hostile operations and bloodshed, would by itself constitute a huge peace dividend. The region has suffered dearly from many wars and military activities and incurred considerable human losses. Furthermore, the conflict has entailed enormous economic costs for the countries in the region. These include, but not limited to, the opportunity cost of devoting scarce resources to defense, disincentives for foreign direct and portfolio investment inflows, the failure to fully exploit the potential of production and services such as tourism, the high risk premium that limits the ability to borrow from external sources, inappropriate factor specialization and restrictions on mobility, welfare losses in terms of inefficient regional trade and financial arrangements, and slow development of joint infrastructure projects (El-Naggar and El-Erian, 1993).

The literature on peace dividends in the region can be divided into two main branches: first, the benefits that the rivals would gain if they cut military expenditure and divert the released resources into more productive activities. Examples include Yildirim, et al. (2005) and DeRouen (2000). This has been reviewed in an earlier section of this survey. Second is the way the region would be transformed in a peace era. Economists and politicians often cite one or more of the following potential 
dividends of a long-lasting and just peace in the region: (1) creating a stable political and economic environment conducive to private and foreign investments, regional tourism, and megaregional projects such as in infrastructure, energy, and water and coastal management; (2) peace would increase the plausibility of regional economic integration and increased trade volumes among the former adversaries; (3) increased regional factor flow and enhanced specialization; (4) governments would be able to implement economic and structural reforms such as strengthening the private sector and reduce the size of the inefficient public sector; and (5) increased foreign aid, although some doubt that the volume of aid would exceed its confrontation-time levels.

Along with the potentially hefty gains from peace are several costs, especially in the short-run. These include transitional bottlenecks caused by shifting resources from military to civilian production, higher transitory unemployment, increased social tensions that result from economic reforms, and the loss of technology spillovers from military to civilian industries.

These benefits and costs are described and analyzed in detail on both the national and regional level in a special volume edited by Fischer, et al. (1993). In particular, there is an elaborate discussion of the specific economic implications of peace for Egypt, Israel, Jordan, Lebanon, Syria, and the Occupied Territories. Emphasis is placed on the gains from reduced military expenditure and channeling of the released resources to more productive sectors, increased private investment and foreign capital inflows, and increased regional integration and trade. A wider regional perspective is nicely drawn by El-Naggar and El-Erian (1993). Another volume that examines peace dividends in general is by Gleditsch, et al. (1996).

In addition to the gains from reductions in military spending, some studies focus on specific potential benefits of peace. For example, Sorensen and Yosha (2003) assess the gains from regional capital and credit market integration in the Middle East. According to them, such integration leads to smoother income and consumption as a result of international diversification of investments. The authors estimate potential gains from sharing risk among the countries in the region to be considerably greater than the potential gain from sharing risk among OECD countries. They find that most of the smoothing of country-specific output shocks are achieved through saving and international transfers.

As for the potential for trade in a peace era, Momani (2007) addresses the Middle East Free Trade Area (MEFTA) that has been proposed by American administrations. She raises doubts on the likelihood of achieving peace and stability through intra-regional economic cooperation. Since Middle Eastern states do not complement one another well - their socio-political systems are relatively traditional and inward-oriented and they have little comparative advantage to increase economic cooperation - the proposed MEFT A would be a hub-and-spoke relationship in which the United States would export manufactured goods to the region and the region's countries would export unprocessed primary goods. According to Momani, such a relationship would be disastrous for the region. Moreover, she argues, peace and stability would not be created because of economic interdependence among Middle Eastern states, as might be desirable, but rather because of their submission to American hegemony in the region.

Another study that casts doubts on realizing peace dividends is that of Ekholm, et al. (1996). They estimate a gravity equation using a sample of countries with mainly outward-oriented market economies to predict post-normalized trade volumes among Middle Eastern countries, and between these countries and Europe. The authors conclude that a successful peace process may not in itself have large direct effects on either trade or growth but rather may lead to sizeable indirect effects. Their results indicate that the potential for trade within the region or with Europe is insignificant, at least in the short-run, and may be greater in the long-run. A gravity equation setup is also used by Arnon, et al. (1996). They predict that while a substantial level of commodity trade might prevail between Israel and the Palestinian economy, a relatively low level of trade is expected with Jordan. Based on their detailed analysis of commodities and services, they identify tourism, health, education, and computer programming as having the highest odds of generating reasonable volumes of trade once peace is achieved.

A more optimistic view is presented by Kilchevsky, et al. (2007). Using events data of dyadic interactions reported in newspapers and wire-services as a measure of conflict, the authors find that economic interdependence among countries in the region helps deter conflict and stabilize the political situation. Despite this, they outline the need for liberal regimes that adhere to the will and welfare of their people before regional interdependence and peace can be realized.

\section{Summary and future research}

This survey reviewed economic aspects of the Israeli-Arab conflict as captured in the extant literature. The goal was not to provide a complete survey of the literature but rather to present a concise and critical assessment of the major studies that address the main economic aspects of the conflict.

The literature leaves a lot to be desired. There is a dire need to compile detailed time series to examine wider and richer issues. Examples include the following: first, to examine the dynamics of the arms race while taking into account "true" measures of military burden, military strength, and weapons arsenals; second, studying the channels through which military spending affects growth, identifying the civilian activities that are affected by military spending, and the magnitude of spillovers from military to civilian activities; third, analyzing the impact of foreign military and civilian aid on the region and whether they stabilize or fuel conflict; fourth, studying the relationship between military outlays and both domestic and external debt, and whether governments tend to borrow to finance military expenditure; and, finally, to provide accurate estimates of the gains from the cessation of hostile activities hoping 
that these would serve as incentives to reach a long-lasting peace. Detailed studies of sectors, activities, and projects that would benefit from peace are very much needed.

\section{Notes}

Aamer S. Abu-Qarn is assistant professor of economics at Ben-Gurion University of the Negev, Beer-Sheva, Israel. He may be reached at aamer@bgu.ac.il.

1. See Beenstock (1998) for estimates for Israel.

2. Beenstock (1998).

3. Sims, et al. (1990).

4. See Dunne, et al. (2005) for a critical review of the models used to examine the defense-growth relationship

5. This is surprising because, unlike Israel, Jordan has no military industry to speak of that could generate spillover effects.

\section{References}

Abu-Bader, S. and A. Abu-Qarn. 2003. "Government Expenditures, Military Spending and Economic Growth: Causality Evidence from Egypt, Israel, and Syria." Journal of Policy Modeling, Vol. 25, No. 6-7, pp. 567-583.

Abu-Qarn, A. and S. Abu-Bader. 2008. "On the Dynamics of the Israeli-Arab Arms Race." Mimeo. Beer-Sheva, Israel: Economics Department, Ben-Gurion University.

Arnon, A., A. Spivak, and J. Weinblatt. 1996. "The Potential for Trade between Israel, the Palestinians and Jordan." World Economy, Vol. 19, No. 1, pp. 113-134.

Beenstock, M. 1998. "Country Survey XI: Defense and the Israeli Economy." Defense and Peace Economics, Vol. 9, No. 3, pp. 171-222.

Bichler, S. and J. Nitzan. 1996. "Military Spending and Differential Accumulation: A New Approach to the Political Economy of Armament - The Case of Israel." Review of Radical Political Economics, Vol. 28, No. 1, pp. 51-95.

Chen, B., Y. Feng, and C. Masroori. 1996. "Collective Action in the Middle East? A Study of Free-Ride in Defense Spending." Journal of Peace Research, Vol. 33, No. 3, pp. 323-339.

Cohen, J., R. Stevenson, A. Mintz, and M. Ward. 1996. "Defense Expenditures and Economic Growth in Israel: The Indirect Link." Journal of Peace Research, Vol. 33, No. 3, pp. 341-352.

Cohen, J. and M. Ward. 1996. "Towards a Peace Dividend in the Middle East: The
New Dynamics of Military Spending," pp. 425-437 in N.P. Gleditsch, et al., eds. The Peace Dividend: Contributions to Economic Analysis, vol. 235. Amsterdam, New York, and Oxford: Elsevier, North-Holland.

DeRouen, K. R., Jr. 1995. “Arab-Israeli Defense Spending and Economic Growth.” Conflict Management and Peace Science, Vol. 14, No. 1, pp. 25-47.

DeRouen, K., Jr. 2000. “The Guns-Growth Relationship in Israel.” Journal of Peace Research, Vol. 37, No. 1, pp. 69-83.

Dunne, J. P., R. Smith, and D. Willenbockel. 2005. "Models of Military Expenditure and Growth: A Critical Review." Defense and Peace Economics, Vol. 16, No. 6, pp. 449-461.

Ekholm, K., J. Torstensson, and R. Torstensson. 1996. "The Economics of the Middle East Peace Process: Are There Prospects for Trade and Growth?" World Economy, Vol. 19, No. 5, pp. 555-574.

El Naggar, S. and M. El Erian. 1993. "The Economic Implications of a Comprehensive Peace in the Middle East," pp. 205-225 in S. Fischer, D. Rodrik, and E. Tuma, eds. The Economics of Middle East Peace: Views from the Region. Cambridge and London: MIT Press.

Fischer, S., D. Rodrik, and E. Tuma. 1993. The Economics of Middle East Peace: Views from the Region. Cambridge and London: MIT Press.

Gleditsch, N.P., O. Bjerkholt, A. Cappelen, R. Smith, and J. P. Dunne. 1996. The Peace Dividend. Amsterdam, New York and Oxford: Elsevier, North-Holland.

Joerding, W. 1986. "Economic Growth and Defense Spending: Granger Causality." Journal of Development Economics, Vol. 21, No. 1, pp. 35-40.

Kilchevsky, A., J. Cason, and K. Wandschneider. 2007. "Peace and Economic Interdependence in the Middle East." World Economy, Vol. 30, No. 4, pp. 647-664.

Kinsella, D. 1994a. "Conflict in Context: Arms Transfers and Third World Rivalries during the Cold War." American Journal of Political Science, Vol. 38, No. 3, pp. 557-581.

Kinsella, D. 1994b. "The Impact of Superpower Arms Transfers on Conflict in the Middle East." Defense and Peace Economics, Vol. 5, No. 1, pp. 19-36.

Kinsella, D. and H. Tillema. 1995. "Arms and Aggression in the Middle East: Overt Military Interventions, 1948-1991." Journal of Conflict Resolution, Vol. 39, No. 2, pp. 306-329.

Lebovic, J. H. and A. Ishaq. 1987. "Military Burden, Security Needs, and Economic Growth in the Middle East." Journal of Conflict Resolution, Vol. 31, No. 1, pp. 106-138.

Linden, M. 1991. "The Dynamics and the Instability of the Middle East Military Expenditures in Years 1955-1984." Defense Economics, Vol. 2, No. 3, pp. 199-208.

Linden, M. 1992. "Military Expenditures, Government Size and Economic Growth in the Middle East in the Period 1973-85." Journal of Peace Research, Vol. 29, 
No. 3, pp. 265-270

Looney, R. and D. Winterford. 1995. Economic Causes and Consequences of Defense Expenditures in the Middle East and South Asia. Boulder, CO: Westview Press. Mayer, J. and R. Rotte. 1999. "Arms and Aggression in the Middle East, 1948-1991: A Reappraisal." Journal of Conflict Resolution, Vol. 43, No. 1, pp. 45-57.

McGuire, M. 1982. "U.S. Assistance, Israeli Allocation, and the Arms Race in the Middle East: An Analysis of Three Interdependent Resource Allocation Processes." Journal of Conflict Resolution, Vol. 26, No. 2, pp. 199-235.

McGuire, M. 1987. "Foreign Assistance, Investment, and Defense: A Methodological Study with an Application to Israel, 1960-1979." Economic Development and Cultural Change, Vol. 35, No. 4, pp. 847-873.

Mintz, A. and M. Ward. 1989. "The Political Economy of Military Spending in Israel." The American Political Science Review, Vol. 83, No. 2, pp. 521-533.

Momani, B. 2007. “A Middle East Free Trade Area: Economic Interdependence and Peace Considered." World Economy, Vol. 30, No. 11, pp. 1682-1700.

Richardson, L. 1960. Arms and Insecurity: A Mathematical Study of Causes and Origins of War. Pittsburgh: Boxwood Press.

Seiglie, C. and P. Liu. 2002. "Arms Races in the Developing World: Some Policy Implications." Journal of Policy Modeling, Vol. 24, No. 7-8, pp. 693-705.

Sims, C., J. Stock, and M. Watson. 1990. "Inference in Linear Time Series Models with Some Unit Roots.” Econometrica, Vol. 58, No. 1, pp. 113-144.

Smith, R., J. P. Dunne, and E. Nikolaidou. 2000. "The Econometrics of Arms Races." Defense and Peace Economics, Vol. 11, No. 1, pp. 31-43.

Sorensen, B. and O. Yosha. 2003. "Financial Market Integration in the Middle East: How Big Is the Peace Dividend?" Israel Economic Review, Vol. 1, No. 2, pp. $1-19$.

Sprecher, C. and K. DeRouen, Jr. 2002. "Israeli Military Actions and Internalization-Externalization Processes." Journal of Conflict Resolution, Vol. 46, No. 2, pp. 244-259.

Toda, H. and T. Yamamoto. 1995. "Statistical Inference in Vector Autoregressions with Possibly Integrated Processes." Journal of Econometrics, Vol. 66, No. 1-2, pp. 225-250.

Yildirim, J., S. Sezgin, and N. Ocal. 2005. "Military Expenditure and Economic Growth in Middle Eastern Countries: A Dynamic Panel Data Analysis." Defense and Peace Economics, Vol. 16, No. 4, pp. 283-295. 